"Sustaining employment through administrative management experiential learning in an open distance learning institution"

AUTHORS Tshilidzi Eric Nenzhelele

Tshilidzi Eric Nenzhelele (2016). Sustaining employment through administrative

ARTICLE INFO management experiential learning in an open distance learning institution. Problems and Perspectives in Management, 14(2-2), 385-392. doi:10.21511/ppm.14(2-2).2016.14

DOI http://dx.doi.org/10.21511/ppm.14(2-2).2016.14

RELEASED ON Monday, 13 June 2016

JOURNAL

"Problems and Perspectives in Management"

FOUNDER

LLC "Consulting Publishing Company "Business Perspectives"

NUMBER OF REFERENCES

0



0

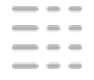

NUMBER OF TABLES

0

(C) The author(s) 2022. This publication is an open access article. 
Tshilidzi Eric Nenzhelele (South Africa)

\title{
Sustaining employment through administrative management experiential learning in an open distance learning institution
}

\begin{abstract}
The supply of business and management graduates to the labor market has grown significantly. However, these graduates still find themselves without employment for years. This is because employment is lagging behind economic growth. As a result, unemployment rate in South Africa has increased from 22\% in 1994 to 25\% in 2014. In response, government, employers and managers are striving to create sustainable employment. However, creating sustainable employment is both challenging and difficult. No wonder that there is a constant cry to establish factors that enable sustainable employment. The aim of this research is to establish the impact of experiential learning in administrative management on sustainable employment. The research is quantitative in nature, and a questionnaire is used to collect data from the respondents. The research establishes that experiential learning in administrative management enables sustainable employment.
\end{abstract}

Keywords: employment, sustainable employment, experiential learning, open distance learning, administrative management. JEL Classification: I23, I25, J21, J64, M10, M51, O15.

\section{Introduction}

Graduation, employment and promotion are the main reasons why most people register for a qualification at a higher education institution (Gokuladas, 2011). While there has been an increase in the number of graduates with Administrative Management qualifications, most of them struggle to find sustainable employment (SE) (Wilton, 2011). This is because employment lags behind economic growth (Palmer, 2009). Moreover, there is a gap between the skills they acquired and the skills required by the employers (Nilsson, 2010).

Due to the lag of employment behind economic growth, the unemployment rate increased from $22 \%$ in 1994 to $25 \%$ in 2014 in South Africa (Stats SA, 2014). To reduce unemployment rate, government, employers and managers are striving to come up with initiatives that enable SE (Biffl and Isaac, 2005). However, this is both difficult and challenging (Corbiére and Lecomte, 2009). SE requires a supportive, stimulating and motivating work environment (Palmer, 2009). MÖller (2014) concludes that more researches are aimed at establishing factors that enable SE be conducted in future.

No research has been conducted to establish the impact of experiential learning in administrative management in open distance learning institution on SE (Palmer, 2009; Procter, 2011). This research is aimed at establishing the impact of experiential learning in Administrative Management on SE. Students registered for an experiential learning module in Administrative Management were used as respondents to a questionnaire.

(C) Tshilidzi Eric Nenzhelele, 2016.

Tshilidzi Eric Nenzhelele, Senior Lecturer, Department of Operations

Management, University of South Africa, South Africa.

\section{Experiential learning}

It is impossible to teach practical exercises theoretically from the book (Cathcart, Greenspan and Quin, 2010). True learning is the result of students' experiences, and the evaluation and reflection of these experiences (Moore, Boyd and Dooley, 2010). Experiential learning (EL) unlocks capabilities because it is about action rather than just learning theory (Jennings and Wargneir, 2010). EL can be implemented by educators in varied disciplines to equip students with hand-on experience and enhance the quality of business education (Clark and White, 2010; Ghose, 2010). It promotes graduates' employability and provides the employer with an additional employee (Peach and Gamble, 2011). EL is, therefore, valuable for future success of both students and employers (Clark and White, 2010).

Although there are many definitions of EL, Kolb's (1984) is the most quoted. Kolb (1984) defines EL as the process whereby knowledge is created through the transformation of experience. According to Kolb, EL is a four stage process. These stages are depicted in Figure 1 and discussed below.

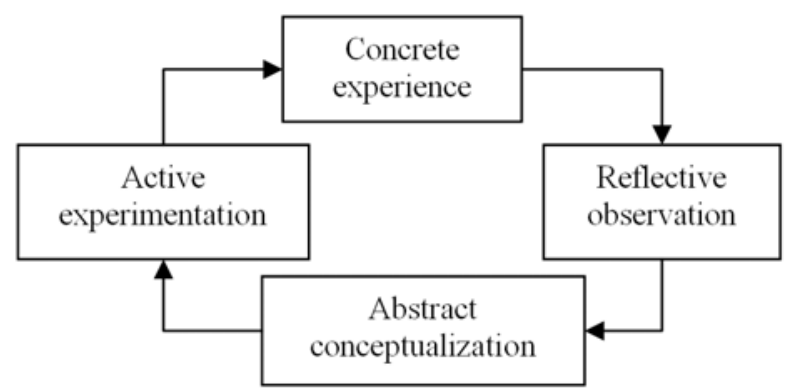

Fig. 1. Kolb's cycle of experiential learning

Source: adapted from Kolb, 1984.

- Concrete experience: the learner must be willing and actively involved in the experience;

- Reflective observation: the learner must be able to reflect on the experience; 
- Abstract conceptualization: the learner must possess and use analytical skills to conceptualize the experience; and

- Active experimentation: the learner must possess decision-making and problem-solving skills in order to use new ideas gained from the experience.

EL is categorized into two different types: one, which is more personal and informal, and another type which is a designed learning event with situations to which the learner is intentionally exposed (Vesper, Kartog, Bishara and Reeves, 2010). It can take many forms including internships, volunteering to work in a firm, and simulation (Clark and White, 2010).

EL provides many benefits to students, faculties and educational institutions, firms/owners/managers, researchers and government policy makers (Hynes and Richardson, 2007). According to Nevin (2001), EL provides learners with fun, exciting and entertaining way of learning. In addition, it creates the right atmosphere for learning, puts value on students' knowledge, skills and experience, enforces sharing of ideas and increases synergistic learning of participants (Smith, Collins and Hannon, 2006).

\subsection{Experiential learning course in} administrative management. The course is entitled "Administrative Practice" because of the EL component in it. This course is offered by University of South Africa (UNISA), the largest open distance learning university in Africa. The purpose of the course is to provide the learners with EL in the National Diploma in Administrative Management. This course enables learners to apply the theory or knowledge they acquired during their first, second and third level of study of Administrative Management. It affords the learner with an opportunity to function in a working environment. The module provides hands-on experience on administrative management, and enables learners to advise any employer on how to set up the office environment.

Upon registration, students receive study materials which include all assignments they must complete throughout the year. One of the assignments they must complete is the EL project which should be completed in a work environment and submitted for final assessment. Other assignments cover theory on EL. The purpose of the theory on EL is to alert learners of what to expect in the work environment. With the help of the university, students are placed at the workplace. They spend two months in the work environment. During this period, they familiarize themselves with the organization in which they are placed; learn the information systems in use; use both written and electronic communication; discover the area that requires insurance; plan the office environment; learn how administrative function supports other organizational functions; learn about quality assurance; ensure that the office observes green principles; expose themselves to facilities management; learn about automated processes in the organization; learn about ergonomic office; discover how the organization decorates its offices; learn about buying; and facilitate meetings. In a nutshell, students learn all about administrative management.

A log book is provided to students and contains all the activities they should complete. After completing each activity, they record evidence of completion in a portfolio of evidence and attach supporting documents. Also, students declare ownership of their portfolio of evidence by attaching a declaration form with a stamp of commissioner of oath. The purpose of the commissioner of oath stamp is to ensure that the students' work is original, and to avoid plagiarism. They make their portfolio presentable by biding or filing it, and get it ready for submission to the university. The portfolio is submitted towards the end of the year for final assessment.

A mentor was allocated to each student by the placement organization. The role of the mentor was to guide the student through the project. At the end of the two months period, the mentor evaluates the student's performance through the use of a standard evaluation form. This form is attached to the final portfolio of evidence which the student submits for final assessment.

\section{Sustainable employment}

SE is defined as having three axes: comprising employment which is ongoing and secure; offers adequate remuneration and working conditions; and is provided by the economy rather than external interventions (McCord and Slater, 2015). It ensures that unemployment remains constant or decreases (McQuaid and Bergmann, 2015). SE eradicates poverty, leads to the realization of productive potential of an employee and enables full utilization of education and skills (McQuaid and Bergmann, 2015; Palmer, 2009). It is therapeutic to people with disabilities (Ross, 2007).

SE should, therefore, receive special attention and its barriers eliminated (Rosen, 1995; McQuaid and Bergmann, 2015). Policies and initiatives that enable it must be implemented (Rosen, 1995; Biffl and Isaac, 2005; Palmer, 2009). Government should invest in higher education, start apprenticeship and empower the private sector as this leads to obtaining SE (El Ghatit and Hanson, 1978; Palmer, 2009). 
Hoven, Ford, Willmot, Hagan and Siegrist (2014) point out that training, work placement and postplacement enable SE. Moreover, it is influenced by job coaching, information and communications technology (ICT) and the level of control the employee has over the firm (Pérotin, 2013; Osuagwo, Agbasonu, Chinwe, Eze and Ummukulthum, 2015). Williams, Fossey and Harvey (2010) established the following factors that influence SE:

- supportive social environment;

- flexible work environment;

- match between the job and the individual's need, interest, enjoyment and feelings;

- desire of the employees to sustain their employment;

- job satisfaction;

- work relationship;

- regular schedule;

- easy to complete tasks;

- physical and emotional wellbeing of employees;

- safe and healthy work environment;

- jobs that promote a feeling of competence and challenge;

- jobs that promise a better future; and

- employment-related motivations.

Although it is possible, creating SE is difficult and challenging (Corbiére and Lecomte, 2009). Sumsion (2007) concludes that due to shortage of teachers, SE is difficult in teaching. Burns (1993) discovers that tourism employers show little concern for SE. Fine (2012) finds that it is difficult for care givers to sustain their employment.

\section{Open distance learning}

There has been a tremendous growth of open distance learning (ODL) institutions in developing countries (Udegbe, 2012). This is due to the development of ICT, particularly, internet-based technology (Ali, 2012). Some of the modern technologies used by ODL institutions include high speed internet connection; computers; $\mathrm{CDs}$ and DVDs, flash drives; radios; and television systems (Ofoegbu, 2009). Because of the use of ICT, particularly, the internet, ODL is described using the terms e-learning (electronic learning) and online learning (Moore and Kearsley, 2005).

ODL took root in many countries as a means to resolve political compulsions, as, also, to fulfill the aspirations of different sections of the people who had missed educational opportunities, not as a matter of individual choice but as compulsions of social and cultural contexts (Rao, 2011). It offers flexibility and teaching approaches that are centered on the student with regard to content, time, place, pace of learning, method of instruction and nature of assessment (Wei,
2010). ODL is characterized by learners' freedom of selection of what, when and where to learn (Sharma and Gupta, 2012). Thus, the objective of ODL is to enhance the opportunities that support education for all and life-long learning (Ofoegbu, 2009).

Unlike in conventional educational institutions, teachers and students are isolated by distance and time in ODL (Udegbe, 2012). Due to distance and lack of contact with students in ODL, there has been a higher failure rate and low graduation rate. This has led government to exert strong pressure on ODL educational institutions to improve student success (Subotzky and Prinsloo, 2011). As a result, ODL institutions provide students support (Wei, 2010).

There are several definitions of ODL. Bouras et al. (1998) define ODL as the process of learning with the use of telematics that is the combination of telecommunication, information and multimedia technology and its services. This definition is limiting ODL to ICT and is, therefore, not inclusive. Moore and Tait (2002) define ODL as approaches that focus on opening access to education and training provision, freeing learners from the constraints of time and place, and offering flexible learning opportunities to individuals and groups of learners. Although it does not mention ICT, this definition is comprehensive. Having considered these definitions and for the purpose of this study, ODL is defined as a system that offers education without boundaries of knowledge content, time and place through the help of ICT, and provides support to ensure learner success.

3.1. UNISA and open distance learning. UNISA is the largest ODL institution in Africa and the longest standing dedicated distance education university in the world. UNISA enrols nearly one-third of all South African students. Founded in 1873 as the University of the Cape of Good Hope, the institution became the first public university in the world to teach exclusively by means of distance education in 1946. Throughout the years, UNISA was the only university in South Africa to have provided all people with access to education, irrespective of race, colour or creed. UNISA offers an unparalleled range of study choices, ranging from short courses and certificate programs to three and four year degrees and diplomas, to over 350000 students almost every year (http://www.unisa.ac.za/Default.asp?Cmd=ViewConte ntandContentID=17765).

According to Pityana (2009), UNISA has the highest foreign student enrolment figures in Africa and provides its teaching and learning and administrative services worldwide. Scott, Yeld and Hendry (2007) found that at UNISA only $30 \%$ of the 2000 first-time student cohort had graduated 
within five years. Moreover, with a further $14 \%$ still registered, $56 \%$ of the cohort had, therefore, discontinued their studies. UNISA is experiencing rapid increase in enrolment and causes operational problems such as late deliveries of study materials (Subotzky and Prinsloo, 2011).

\section{Methodology}

A survey was undertaken to collect data from Administrative Practice students registered at UNISA for the academic year 2011. A questionnaire with open-ended, and closed-ended questions were used to collect data from students. The questionnaire was sent to all students (330) registered for Administrative Practice via e-mail. Students were requested to attach the completed questionnaire to their project portfolio and submit them all together. Those who failed to attach the questionnaire to their project portfolio scanned and e-mailed or faxed the questionnaire to the lecturer. Of the 330 students, only 270 were admitted to the examination allowing them an opportunity to submit their project portfolio. Only 97 usable questionnaires were received from the students. This led to a response rate of $35.93 \%$. This could be because the questionnaire was sent to students closer to the due date for submission of the project portfolio and some students might have missed it or accessed it after the due date.

\section{Results}

Regarding placement, $38.1 \%$ of the students found the placement themselves; $4.1 \%$ were assisted by the university to find placement; $3.1 \%$ were placed in a family business; $4.1 \%$ were employed at the university; and $50.5 \%$ were already employed. Of the 97 students, $56.7 \%$ indicated that two months were long enough for the completion of the project whereas $43.3 \%$ indicated that it was short. Those who indicated that two months were shorter gave the following summarized reasons:

- time is required to adjust to the work environment $(4.8 \%)$

- it is difficult to complete the project if you are registered for many other modules $(2.4 \%)$

- there is so much to be learned (83.3\%)

- mentors are not always available to assist because of their tight schedule $(9.5 \%)$

When asked what the suitable time frame in months should be, $6.2 \%$ of the students chose three months; $19.6 \%$ chose four months; $1 \%$ chose five months; $10.3 \%$ chose six months; $2.1 \%$ chose seven months; and the remaining $60.8 \%$ were happy with two months. Students were placed in the following industries: public service (11.3\%); transport, storage and communication (8\%); educational services
(8.2\%); agriculture, forestry and fishing (7.2\%); financing, insurance, real estate and business services (7.2\%); medical, dental, other health and veterinary and business services $(7.2 \%)$; social and related community services $(7.2 \%)$; mining and quarrying $(5.2 \%)$; electricity, gas and water $(4.1 \%)$; law (3.1\%); agencies and other services (3.1\%); food, beverages and tobacco $(2.1 \%)$; paper, printing and publishing $(2.1 \%)$; machinery and related items $(2.1 \%)$; manufacturing $(2.1 \%)$; construction $(2.1 \%)$; retail trade $(2.1 \%)$; safety and security $(1 \%)$; office automation (1\%); IT services (1\%); government agency (1\%); equipment program sector (1\%); laundry (1\%); commercial and industrial auditing (1\%); wood, wood products and furniture (1\%); chemicals, and chemical, rubber and plastic products $(1 \%)$; catering and accommodation (1\%); and long-term insurers (1\%).

As it pertains to the project content, $81.4 \%$ agreed that the project covers everything about the current administrative practice; $89.6 \%$ agreed that the project deals with relevant administrative duties; 90.7\% agreed that the project prepares students for the work environment; $82.4 \%$ indicated that the project was challenging; $85.6 \%$ indicated that the project made them want to know more about the organization they were placed in; 53.6\% indicated that the project was relevant to the workplace; $68.1 \%$ indicated that the project covers things that are happening in the workplace; and $61.8 \%$ indicated that the project should not be changed. The following additional comments were provided concerning the project content:

- it develops skills such as communication, team work; sending of e-mails and report writing, punctuality and attendance, and develops awareness to the workplace culture;

- it gives an opportunity to get out of the comfort zone;

- it helps students to think critically;

- it prepares students for the work environment;

- it's difficult to find placement;

- it's difficult to get information from larger organization;

- some organizations don't have needed equipment;

- students get employed due to experiential learning; and

- university must align the course content with what companies are doing.

In summary, the additional comments indicate that while some students experienced difficulties in finding placement and required equipment and extracting information from large organizations, the project helped them to get out of their comfort zone. 
Although some students suggested that the project content be aligned with what the organizations are doing, many found it enriching. The project content helped students to secure employment, think critically, communicate and act professionally in a work environment.

Table 1 indicates the overall impression of the EL project on students. The majority (94\%) of students indicated that the experiential learning project helps one to get employment. The majority $(91.8 \%)$ of students indicated that the experiential learning project enables networking with other people leading to employment opportunities. Most (94.8\%) of the students indicated that the experiential learning project creates a positive attitude about employment. Almost all (99\%) of the students indicated that the EL project prepares an individual for employment. Most (90\%) of the students indicated that the EL project provides employability skills. The majority $(89.7 \%)$ of students indicated that the EL project enables SE.

Table 1. Frequency of students' overall impression of the experiential learning project in administrative management

\begin{tabular}{|l|c|c|}
\hline & Frequency & Percentage \\
\hline $\begin{array}{l}\text { Administrative practice can help one to get } \\
\text { employment }\end{array}$ & 92 & 94.8 \\
\hline $\begin{array}{l}\text { One gets to network with working people } \\
\text { making it easy to get employment }\end{array}$ & 89 & 91.8 \\
\hline $\begin{array}{l}\text { It makes one is attitude about employment } \\
\text { positive }\end{array}$ & 92 & 94.8 \\
\hline It prepares one for employment & 96 & 99.0 \\
\hline $\begin{array}{l}\text { It provides one with most skills needed for } \\
\text { employment }\end{array}$ & 90 & 92.8 \\
\hline $\begin{array}{l}\text { It makes an employed person to sustain } \\
\text { his or her job }\end{array}$ & 87 & 89.7 \\
\hline
\end{tabular}

Students wrote the following additional comments regarding their impression of the overall experiential learning project:

- All students should do experiential learning modules.

- Doing experiential learning without a salary is a challenge.

- Finding a placement is such a great challenge.

- I now possess problem-solving skills and ready to apply for management positions.

- It is a great experience and both the student and the employer benefit. Skills have improved and made me ready to challenge new positions within the organization, as well as outside. The project is recommended for managers.

- It is a very relevant project and an eye opener.

- It is an enjoyable project. However, time was a biggest challenge. Working experience came in hand with the completion of the activities. It helps in doing research over the internet.
- It was difficult to perform certain activities.

- Thanks to the enterprise that placed me.

- The employer promised me a job.

- The project was difficult to complete. It must be simplified.

- The experiential learning project is enjoyable. However, time is a challenge when you have a family and work to take care of. The internet assisted a lot with research.

- The experiential learning must be based on the kind of work the students do at their workplace.

- This project builds confidence and self-esteem. It leads someone to help the community and those in need.

- To provide students with an opportunity to network and apply theory into practice.

- Transport money was such a challenge but I learned a lot from this experiential learning.

- Visits to students at the workplace should be done.

- Experiential learning exposes students to the work environment and gets them out of their comfort zone. It provides students with self-confidence.

- Experiential learning has instilled some confidence and the student feels ready for employment.

- Experiential learning helped me to find a temporary job where I was placed.

- Experiential learning helps students to find jobs. It equips students with work experience.

- Experiential learning increases self-confidence and creates a leader in students. It exposes one to public speaking.

- Experiential learning is very helpful and improves skills but the time allocated is too short.

- Experiential learning is very helpful for students who are not working, and it boosts selfconfidence.

- Experiential learning is very helpful to students. It develops awareness of the work environment and business opportunities, exposes students to interview panels and working under pressure.

- Experiential learning is very important for students. It's good for networking, and building confidence, and geting good at operating machineries.

- Experiential learning made work easier.

- Experiential learning prepares students to work with documentation and covers all admin aspects.

- Experiential learning reveals lots of weaknesses in the work environment.

- Experiential learning success is dependent on both the students and the employer's commitment.

- You get exposed to different jobs and liaise with senior management. 
In brief, the additional comments reveal that some students found the EL project difficult and challenging due to limited time, lack of salary and money for transport, and family and work pressure. However, the additional comments recommend that all university students should do EL modules because they equip students with work related skills such as problemsolving, general management, research, networking, communication, pressure handling, equipment operation, and document management. Moreover, the additional comments indicate that some students found the EL projected enjoyable because it gave them work experience and self-confidence. In addition, the additional comments point out that, though the EL project needs alignment to the work environment and constant visit of the lecturers to the work environment, it helped some students to handle interviews, secure employment, be community players, and get out of the comfort zone. Some students conclude that a successful EL project reveals the weaknesses of the work environment and relies on the commitment of both students and employers.

5.1. Obtaining employment. Of the 97 students that participated in the survey, $22(22.68 \%)$ were unemployed before work placement for EL. The remaining $75(77.32 \%)$ students were employed before work placement for EL. Table 2 indicates the results pertaining to obtaining employment due to EL. Of those that were not employed before placement for EL, 9.1\% indicated that they were employed as a result of EL, $13.6 \%$ indicated that they were employed by the organization that placed them for EL, and $13.6 \%$ were employed in other organization except the one that placed them for EL.

Table 2. Frequency on obtaining employment due to experiential learning project

\begin{tabular}{|l|c|c|}
\hline & Frequency & Percentage \\
\hline I am employed after being placed for two months & 2 & 9.1 \\
\hline $\begin{array}{l}\text { I am employed where I did my experiential } \\
\text { learning }\end{array}$ & 3 & 13.6 \\
\hline $\begin{array}{l}\text { I am employed in another firm except the one } \\
\text { where I did my experiential learning }\end{array}$ & 3 & 13.6 \\
\hline
\end{tabular}

5.2. Sustaining employment. Students who were employed before registering for the EL module were asked about the impact of EL on SE. $98.7 \%$ of the employed students indicated that the EL project made them confident in their work. Sixty three (84\%) indicated that their employer was impressed with their work due to EL. Thirty six (48\%) of the students indicated that they will soon be promoted due to the EL project. Sixty two (82.7\%) of the students indicated that their attitude about work has changed due to EL. Thirty nine (52\%) of the students indicated that they will keep their jobs for one to two years due to the EL project. Thirty nine (52\%) of the students indicated that they will keep their jobs for three to five years due to the EL project. Table 3 indicates the results for employment sustainability.

Table 3. Frequency on sustainable employment due to experiential learning project

\begin{tabular}{|l|c|c|}
\hline & Frequency & Percentage \\
\hline $\begin{array}{l}\text { Administrative practice has made me } \\
\text { confident in my work }\end{array}$ & 74 & 98.7 \\
\hline $\begin{array}{l}\text { My employer is impressed with my work } \\
\text { because of administrative practice }\end{array}$ & 63 & 84.0 \\
\hline $\begin{array}{l}\text { I will soon get promoted because of } \\
\text { administrative practice }\end{array}$ & 36 & 48.0 \\
\hline $\begin{array}{l}\text { My attitude about employment has changed } \\
\text { because of administrative practice }\end{array}$ & 62 & 82.7 \\
\hline $\begin{array}{l}\text { I will keep my job for the next one to two } \\
\text { years because of administrative practice }\end{array}$ & 39 & 52.0 \\
\hline $\begin{array}{l}\text { I will keep my job for the next three to five } \\
\text { years because of administrative practice }\end{array}$ & 39 & 52.0 \\
\hline
\end{tabular}

\section{Discussion}

While unemployment rate is very high in South Africa, higher education institutions have a role to play in producing graduates who are employable. Graduates should not only be equipped with skills to obtain employment but they should also be able to sustain the employment. Though majority of the students who participated in this research were already employed before registering for the EL project, some of them who were not employed managed to obtain employment. Some obtained employment where they were placed, while some found employment elsewhere.

The EL project in administrative management instilled confidence in those who were employed before registering for the module. They were able to impress their employer with their improved performance on the job. It made them confident enough to believe that they will soon be promoted. Their attitude changed to an extent that they believed they will keep their employment for the next five years.

Almost all students were impressed about the overall EL project. They admit that the EL project helps in obtaining employment. This is because it gives them an opportunity to connect with people who are employed and, possibly, in position of power. Moreover, they believed that the EL project equips them with skills required to secure employment. They agreed that the project creates a positive attitude and enables one to sustain employment. Additionally, students commented that the EL project though challenging and difficult due to limited time, lack of salary and work and family pressure, instils self-confidence, creates opportunities to network and offers work experience. They further comment that the EL project raises awareness of the work environment, 
exposes the weaknesses of the work environment and enables students to put theory into practice. They found the project to be relevant to the work environment and enjoyable.

\section{Conclusion}

Notwithstanding that it is challenging and difficult, it is possible to achieve SE. It has been proven beyond doubt that education enables SE. This research found that EL project in administrative management has a positive influence on obtaining SE. Students who did not have employment secured employment due to the EL project. EL project in administrative management enhances selfconfidence and positive attitude towards obtaining
SE. It enables students to network with employed individuals including senior management increasing the chances of securing SE. It does so by equipping them with skills and confidence. It also enables students to impress their employers with work performance. It lets employed student to sustain employment for up to five years.

This research was delimited to students registered for a module in administrative management in an open distance learning institution. The research was limited to the students who secured work placement. Therefore, future research should be conducted across different experiential learning modules in different field of specialization.

\section{References}

1. Ali, E.A. (2011). Challenges before open and distance learning: global perspective and the experience of open university Malaysia. International Conference cum Workshop: Vardhaman Mahaveer Open University, Kota, Rajasthan, India, 7-9 March 2011.

2. Arrowsmith, C., Bagoly-Simo, P., Finchum, A., Oda, K. and Pawson, E. (2011). Student employability and its implications for geography curricula and learning practices, Journal of geography in higher education, 35 (3), pp. 365-377.

3. Biffl, G. and Isaac, J.E. (2005). Sustaining employment of older workers in an ageing society. Paper presented at the Australian Centre for Research in Employment and Work (ACREW) Inaugural Conference on Shifting the Boundaries of Employment and Work, Melbourne, June 24 to 25, 2005, pp. 1-77.

4. Bouras, C., Destounis, P., Garofalakis, J., Gkamas, A., Sakalis, G., Sakkopoulos, E., Tsaknakis, J. and Tsiatsos, T. (2000). Efficient web-based open and distance learning services, Telematics and Informatics, 17 (1), pp. 213-237.

5. Burns, P.M. (1993). Sustaining tourism employment, Journal of Sustainable Tourism, 1 (2), pp. 81-96.

6. Cathcart, E.B., Greenspan, M. and Quin, M. (2010). The making of a nurse manager: the role of experiential learning in leadership development, Journal of Nursing Management, 18 (1), pp. 440-447.

7. Clark, J. and White, G.W. (2010). Experiential learning: a definitive edge in the job market, American Journal of Business Education, 3 (2), pp. 115-118.

8. Corbiére, M. and Lecomte, T. (2009). Vocational services offered to people with severe mental illness, Journal of Mental Health, 18 (1), pp. 38-50.

9. Fine, M.D. (2012). Employment and informal care: sustaining paid work and care giving in community and homebased care, Ageing International, 37 (1), pp. 57-68.

10. Ghatit, A.Z. and Hanson, R.W. (1978). Variables associated with obtaining and sustaining employment among spinal cord injured males: a follow-up of 760 veterans, Journal of Chronic Diseases, 31 (1), pp. 363-369.

11. Ghose, N. (2010). Enhancing global competitiveness through experiential learning: insights into successful programming, American Journal of Business Education, 3 (7), pp. 1-6.

12. Hoven, H., Ford, R., Willmot, A., Hagan, S. and Siegrist, J. (2014). Job coaching and success in gaining and sustaining employment among homeless people, Research on Social Work Practice, pp. 1-7. Available at: http://www.unisa.ac.za/Default.asp?Cmd=ViewContentandContentID=17765. Accessed on 22 November 2012.

13. Hynes, B. and Richardson, I. (2007). Entrepreneurship education: a mechanism for engaging and exchanging with the small business sector, Education + Training, 49 (8/9), pp. 732-744.

14. Jennings, C. and Wargnier, J. (2010). Experiential learning - a way to develop agile minds in the knowledge economy? Development and Learning in Organizations, 24 (3), pp. 14-16.

15. Kolb, D. (1984). Experiential learning: Experience as the source of learning and development. Englewood Cliffs, NJ: Prentice Hall.

16. McCord, A. and Slater, R. (2015). Social protection and graduation through sustainable employment, IDS Bulletin, 46 (2), pp. 134-144.

17. McQuaid, R. and Bergmann, A. (2015). Sustainable employment, integration and sustainable energy development. World Association for Sustainable Development WASD conference, Istanbul, June 2015, pp. 1-13.

18. Moore, C., Boyd, B.L., Dooley, K.E. (2010). The Effects of Experiential Learning with an Emphasiz on Reflective Writing on Deep-Level Processing of Leadership Students, Journal of Leadership Education, 9 (1), pp. 36-52.

19. Moore, M.G. and Kearsley, G. (2005). Distance education: A systems view. $2^{\text {nd }}$ edition. Belmont, CA: Wadsworth.

20. Moore, M. and Tait, A. (2002). Open and Distance Learning: Trends, Policy and Strategy Considerations. Paris: UNESCO.

21. MÖller, J. (2014). Prosperity, sustainable employment and social justice: Challenges for the German labor market in the twenty-first century, International Journal of Education and Vocational Guidance, 14 (1), pp. 35-46. 
22. Nauta, A., Van Vianen, A., Van der Heijden, B., Van Dam, K. and Willemsen, M. (2009). Understanding the factors that promote employability orientation: the impact of employability culture, career satisfaction, and role breadth self-efficacy, Journal of Occupational and Organizational Psychology, 82 (2), pp. 233-251.

23. Nilsson, S. (2010). Enhancing individual employability: the perspective of engineering graduates, Education + Training, 52 (6/7), pp. 540-551.

24. Nevin, T. (2001). Business skills in jail, African Business, 1 (1), pp. 41-42.

25. Ofoegbu, I.F. (2009). Female access to basic education: a case for open distance learning (ODL), Edo Journal of Counseling, 2 (1), pp. 46-57.

26. Palmer, R. (2009). Skills development, employment and sustained growth in Ghana: sustainability challenges, International Journal of Educational Development, 29 (1), pp. 133-139.

27. Peach, D. and Gamble, N. (2011). Scoping Work-Integrated Learning Purposes, Practices and Issues, Professional and Practice-based Learning, 7 (1), pp. 169-186.

28. Pityana, N.B. (2009). Open distance learning in the developing world: trends, progress and challenges. $23 \mathrm{rd}$ ICDE World Conference on Open Learning and Distance Education. "Flexible Education for All: Open - Global Innovative”, Maastricht, the Netherlands, 7 - 10 June 2009, pp. 1-18.

29. Procter, C. (2011). Employability and entrepreneurship embedded in professional placements in the business curriculum, Journal of Chinese Entrepreneurship, 3 (1), pp. 49-57.

30. Pérotin, V. (2013). You are free to share and to remix, you must attribute the work worker cooperatives: good, sustainable jobs in the community, Journal of Entrepreneurial and Organizational Diversity, 2 (2), pp. 34-47.

31. Rao, P.K. (2011). Enrolment, success rate and expenditure in open and distance learning - the experience of the first Open University in India, Journal of Open Schooling, 2 (1), pp. 34-43.

32. Rothwell, A., Jewell, S. and Hardie, M. (2009). Self-perceived employability: investigating the responses of postgraduates students, Journal of Vocational Behavior, 75 (2), pp. 152-161.

33. Rosen, S.M. (1995). Achieving and sustaining full employment, Journal of Public Health Policy, 16 (3), pp. $286-303$.

34. Scott, I., Yeld, I. and Hendry, J. (2007). A case for improving teaching and learning in South African higher education. Pretoria: The Council on Higher Education.

35. Sharma, S. and Gupta, S. (2012). The Virtual Classroom: The role of ICT in open and distance learning, International Journal of Computer, Communication and Emerging Technology, 1 (1), pp. 8-12.

36. Smith, A.J., Collins, L.A. and Hannon, P.D. (2006). Embedding new entrepreneurship programs in UK higher education: challenges and considerations, Education + Training, 48 (8/9), pp. 555-567.

37. Subotzky, G. and Prinsloo, P. (2011). Turning the tide: a socio-critical model and framework for improving student success in open distance learning at the University of South Africa, Distance Education, 32 (2), pp. 177-193.

38. Sumsion, J. (2007). Sustaining the employment of early childhood teachers in long day care: a case for robust hope, critical imagination and critical action, Asia-Pacific Journal of Teacher Education, 35 (3), pp. 311-327.

39. Udegbe, B. (2012). Attitudes of prospective human resource personnel towards distance learning degrees, Online Journal of Distance Learning Administration, $15 \quad$ (1). Available at: http://www.westga.edu/ distance/ojdla/spring151/udegbe.html. Accessed on 12 December 2012.

40. Vesper, J., Kartoglu, Ü., Bishara, R. and Reeves, T. (2010). A case study in experiential learning: pharmaceutical cold chain management on wheels, Journal of Continuing Education in the Health Professions, 30 (4), pp. 229-236.

41. Wei, R. (2010). China's radio and TV universities: reflections on theory and practice of open and distance learning, Open Learning, The Journal of Open, Distance and e-Learning, 25 (1), pp. 45-56.

42. Williams, A., Fossey, E. and Harvey, C. (2010). Sustaining employment in a social firm: use of the Work Environment Impact Scale v2.0 to explore views of employees with psychiatric disabilities, British Journal of Occupational Therapy, 73 (11), pp. 531-539.

43. Wilton, N. (2011). Do employability skills really matter in the UK graduate labor market? The case of business and management graduates, Work, Employment and Society, 25 (1), pp. 85-100. 